\title{
Ameliorating the effects of climate change through organic agriculture system
}

\author{
AJEET KUMAR, DIWAKAR PASWAN, C.S. CHOUDHARY, BRIJESH KUMAR AND ANJANA ARUN
}

Received : $11.10 .2014 ;$ Accepted : 30.11 .2014

\begin{tabular}{l}
\hline MEMBERS OF RESEARCH FORUM \\
Corresponding author : \\
AJEET KUMAR, Regional Research \\
Station, Agwanpur, SAHARSA(BIHAR) \\
INDIA \\
Email: ajeetbau@ gmail.com
\end{tabular}

Co-authors :

C.S. CHOUDHARY, DIWAKAR PASWAN AND ANJANA ARUN,

Regional Research Station, Agwanpur, SAHARSA (BIHAR) INDIA

BRIJESH KUMAR, Regional Research Station, Agwanpur, SAHARSA(BIHAR) INDIA

\begin{abstract}
Summary
The paper attempts to explore research findings focusing on the climate change impact on organic agriculture and its impact on climate change through scientific literature review. This review reveals that climate change and agriculture are closely linked and interdependent. Compared to conventional agriculture, organic agriculture is reported to be more efficient and effective both in reducing GHGs $\left(\mathrm{CO}_{2}, \mathrm{CH}_{4}\right.$ and $\left.\mathrm{N}_{2} \mathrm{O}\right)$ emission mainly due to the less use of chemical fertilizers and fossil fuel. Organic agriculture also reported to be climate change resilience farming systems as it promotes the proper management of soil, water and biodiversity by acting as a good options for adaptation to climate change. But, due to lack of proper research, the contribution of organic agriculture for climate change adaptation and mitigation is yet to be known. It is argued that organic agriculture positively contributes to offset negative impacts of climate change, but there is inadequate systematic data to substantiate this fact.
\end{abstract}

Key words : Adaptation, Climate change, Greenhouse gases mitigation, Organic agriculture

How to cite this article : Kumar, Ajeet, Paswan, Diwakar, Choudhary, C.S., Kumar, Brijesh and Arun, Anjana (2014). Ameliorating the effects of climate change through organic agriculture system . Asian J. Soil Sci., 9(2): 318-324. 